\title{
PENGARUH STORE IMAGE DAN PERCEIVED PRICE TERHADAP PRIVATE LABEL BRAND PRESTIGE PADA SUPERMARKET HERO DI JAKARTA
}

\author{
Selly Rosa Meliana ${ }^{1}$, Andreas Wijaya ${ }^{2}$ \\ ${ }^{I}$ Manajemen, Universitas Bunda Mulia, Jakarta, sherlyrosa05@gmai.com \\ ${ }_{2}^{2}$ Manajemen, Universitas Bunda Mulia, Jakarta, Awijaya@bundamulia.ac.id
}

\begin{abstract}
ABSTRAK:
Negara Indonesiaadalah negara yang memiliki pertumbuhan private label dengan angka yang lumayan signifikan jika di kelola dengan baik. Hal tersebut menunjukkan bahwa ada peluang yang cukup besar bagi perkembangan private label.Tujuan penelitian ini adalah untuk mengetahui seberapa besar pengaruh store image dan perceived price terhadap private label brand.Penelitian ini mengambil objek Supermarket Hero sebagai tempat untuk diteliti. Jenis data yang digunakan yaitu data primer yang diperolah dari kuesioner yang diukur menggunakan skala likert. Penelitian ini menggunakan teknik non probability sampling sebagai teknik dalam pengumpulan data. Sampel yang terkumpul dalam penelitian ini berjumlah 180 responden. Variabel yang diteliti dalam penelitian ini yaitu store image dan perceived price sebagai variabel bebas, private label brand prestige sebagai variabel terikat. Analisis data menggunakan PLS-SEM dengan softwareSmartPLS 3.0.

Hasil pengolahan data menemukan bahwa $\mathrm{H} 1$ diterima karena terdapat pengaruh yang positif dan signifikan dariStore Image terhadap Perceived quality pada Supermarket Hero, dengan nilai uji sebesar 3,689, H2 diterima karenaStore Image memiliki pengaruh yang signifikan terhadap Loyalty pada, dengan nilai signifikansi sebesar 3,263. H3 diterima dilihat dari Store Image memiliki pengaruh yang signifikan terhadap Brand Awareness pada Supermarket Hero, dengan nilai uji signifikansi sebesar 3,052. H4 diterima dilihat dariPerceived price memiliki pengaruh yang signifikan terhadap Perceived quality pada Supermarket Hero, dengan nilai uji signifikansi sebesar 7,039.Selanjutnya H5 diterima dilihat dari Perceived price memiliki pengaruh yang signifikan terhadap Loyalty pada Supermarket Hero, dengan nilai uji signifikansi sebesar 6,356. H6 Diterima dilihat dariPerceived price memiliki pengaruh yang signifikan terhadap Brand Awareness pada Supermarket Hero, dengan nilai uji signifikansi sebesar 5,383.Berdasarkan hasil penelitian, Supermarket Hero harus meningkatkan pelayanan lebih baik dan citra toko yang lebih baik agar konsumen lebih merasa nyaman dan lebih loyal pada Supermarket Hero
\end{abstract}

Kata Kunci: Store image, Perceived Price, Perceived Quality, Loyalty, Brand Awareness/Associations, Private Label Brand Prestige

\section{ABSTRACT:}

Private label ini Indionesia growth rapidly significant. This shows that there is considerable opportunity for the development of private labels. The purpose of this study was to determine how much influence the store image and perceived price have on the private label brand. This research takes Hero Supermarket objects as a place to 


\section{National Conference of Creative Industry: \\ Sustainable Tourism Industry for Economic Development}

Universitas Bunda Mulia, Jakarta, 5-6 September 2018

E- ISSN No: 2622-7436

study. The type of data used is primary data obtained from the questionnaire with likert scale measurement. This study uses non-probability sampling technique as a technique in data collection. The sample collected in this study amounted to 180 respondents. The variables examined in this study are store image and perceived price as independent variables, private label prestige brand as the dependent variable. Data analysis using PLS-SEM with Smart PLS 3.0 software.The data processing results found that H1 was accepted because there was a positive and significant influence from the Store Image on Perceived quality in Hero Supermarket, with a test value of 3.689, H2 was received because the Store Image had a significant influence on the Loyalty, with a significance value of 3.263. H3 received from the Store Image has a significant influence on Brand Awareness on Hero Supermarket, with a significance test value of 3.052. H4 is accepted seen from the Perceived price has a significant effect on Perceived quality in Hero Supermarket, with a significance test value of 7.039. Then H5 is accepted seen from the Perceived price has a significant influence on Loyalty in Hero Supermarket, with a significance test value of 6.356. H6 Received seen from Perceived price has a significant influence on Brand Awareness on Hero Supermarket, with a significance test value of 5.383. Based on the results of the research, Hero Supermarket must improve better service and better store image so that consumers feel more comfortable and more loyal to the Hero Supermarket

Keywords: Store image, Perceived Price, Perceived Quality, Loyalty, BrandAwareness/Associations, Private Label Brand Prestige

\section{PENDAHULUAN}

Di tengah persaingan yang semakin ketat ini, keunggulan kompetitif yang dimiliki oleh peritel dapat memberikan kekuatan dalam menghadapi persaingan. Banyak peritel yang memiliki jaringan yang luas dalam mengembangkan produk nya, salah satu strateginya adalah mengembangkan private label. Berdasarkan riset Nielsen tahun 2008, Indonesia merupakan salah satu Negara yang mencatat pertumbuhan private label dengan angka yang lumayan signifikan. Hal tersebut menunjukkan bahwa ada peluang yang cukup besar bagi perkembangan private label jika di kelola dengan baik. Kemunculan private label juga merupakan suatu bentuk inovasi dari para pengecer yang di tawarkan dengan harga terjangkau dan kualitas yang terjamin. (www.mix.co.id).

Hero Group mendirikan Supermarket Hero sebagai ritel modern pertama di Indonesia yang di dirikan pada tanggal 23 Agustus1971 oleh almarhum Muhammad $\underline{\text { Saleh Kurnia di Jalan Falatehan dengan konsep gerai modern yang menawarkan produk }}$ premium termasuk produk impor. Hero menjadi jaringan ritel pertama yang memperkenalkan produk private label dengan merek Hero Save yang sekarang berubah nama menjadi Hero. Sesuai dengan wawancara awal yang dilakukan dengan salah satu manager toko di kantor pusat Hero Group yaitu Bapak Ageng Andreas Yudhistira dan Ibu Nancy Carolina selaku Ketua Merchendiser Hero Group yang mengatakan bahwa produk private label Hero bukan lagi bernama Herosave melainkan Hero yang sama dengan nama toko nya, dibuat sama agar masyarakat mudah mengingatnya dan Supermarket Hero lebih dikenal oleh masyarakat. Dengan ada nya private label akan menambah keuntungan bagi Supermarket Hero sendiri, terutama dalam penjualannya yang meningkat. private label Hero lebih murah dibandingkan dengan competitor lain, 


\section{National Conference of Creative Industry: \\ Sustainable Tourism Industry for Economic Development}

Universitas Bunda Mulia, Jakarta, 5-6 September 2018

E- ISSN No: 2622-7436

kualitas nya 99\% sama dengan atau lebih baik dari pada kualitas produk brenchmark nya.

Tujuan dari penelitian ini adalah untuk mengetahui (1) apakah terdapat pengaruh darivariabel Store Image terhadap variabel Perceived Quality pada Private Label Brand, (2) apakah terdapat pengaruh variabel Store Image terhadap variabel Loyalty pada Private Label Brand, (3) apakah terdapat pengaruh variabel Store Image terhadap variabel Brand Awareness/Associations pada Private Label Brand?(4) apakah terdapat pengaruh variabel Perceived Price terhadap variabel Perceived Quality pada Private Label Brand? (5) apakah terdapat pengaruh variabel Perceived Price terhadap variabel Loyalty pada Private Label Brand?(6) apakah terdapat pengaruh variabel Perceived Price terhadap variabel Brand Awareness/Associations pada Private Label Brand

\section{TINJAUAN PUSTAKA}

\section{Private Label Brand Prestige}

Private label brand prestigedidasarkan pada konsep teori ekuitas merek. Dalam hal yang paling mendasar dari ekuitas merek dapat dinyatakan sebagai kata, nilai atau modal dari suatu merekdan sering digolongkan sebagai aset tidak berwujud ke perusahaan. (Keller, 2012 dalam Beneke \& Zimmerman, 2014). Private Label Brand juga disebut sebagai merek toko sendiri yang dimiliki dan dikendalikan oleh pengecer tertentu dan dijual hanya dalam rantai ritel mereka. (Herstein and Jaffe, 2007; Kumar and Steenkamp, 2007 dalam Beneke \& Zimmerman, 2014).Menurut Beneke, 2010; Lamey et al., 2007 dalam Beneke \& Zimmerman, 2014private label brand saat ini terwakili di hampir setiap kategori produk, khususnya di sektor bahan makanan. Citra toko sebelumnya telah ditemukan mempengaruhi evaluasi konsumen produk private label brand dan dengan demikian dianggap sebagai yang terdahulu dalam kerangka ini. (Diallo, 2012; Liljander et al., 2009; Semeijn et al.., 2004; Vahie and Paswan, 2006; Richardson et al., 1996 dalam Beneke \& Zimmerman, 2014)

\section{Perceived Quality}

Menurut (Zeihalm, 1988; Richardson et al,. 1996; Bao et al,. 2011)kualitas yang dirasakan dapat diartikan sebagai penilaian global konsumen atas keunggulan keseluruhan produk. Kualitas yang dirasakan telah terbukti secara signifikan mempengaruhi niat konsumen untuk membeli produk label pribadi. Kualitas yang dirasakan adalah efek yang tergantung pada faktor situasional dan personal karena termasuk kualifikasi persepsi dari kualitas yang dirasakan oleh merek meningkat atau menurun, begitu jugua dengan Brand Prestige. (Keller, 2012; Villarejo-Ramos and Sanchez-Franco, 2005; Yo, et al., 2000; Aaker, 1991 dalam Beneke \& Zimmerman, 2014).

\section{Brand Awareness and Associations}

Brand Awareness \& Associations adalah cerminan sejauh mana merek yang di kenali atau di ingat oleh konsumen dari informasi yang di dapat. (Keller, 2012; Yoo et al, 2000; Aaker, 1991; Holden, 1993). Menurut Low and Lamb, 2000 dalam Beneke \& Zimmerman, 2014hal ini memungkinkan konsumen untuk memproses, mengatur dan 


\section{National Conference of Creative Industry: \\ Sustainable Tourism Industry for Economic Development}

Universitas Bunda Mulia, Jakarta, 5-6 September 2018

E- ISSN No: 2622-7436

mendapatkan informasi dari ingatan konsumen untuk membantu dalam keputusan pembelian. Brand Associations terkait dengan informasi tentang apa yang ada di benak pelanggan tentang merek, baik positif atau negatif, terhubung kesimpulan memori otak pelanggan. (Emari et al., 2012). Brand Awareness adalah bagaimana konsumen mengasosiasikan merek dengan produk tertentu yang ingin mereka miliki. Kesadaran merek sangat diperlukan untuk proses komunikasi yang muncul diatas pikiran. (Macdonald and Sharp, 2003; Netemeyer et al., 2004 dalam Beneke \& Zimmerman, 2014). Menurut Pouromid and Iranzadeh, 2012 semakin tinggi asosiasi merek dalam produk, semakin diingat oleh konsumen dan konsumen akan loyal terhadap merek. Konsumen menerima kesadaran merek melalui saluran komunikasi pemasaran yang efektif seperti televisi, ponsel dan iklan online karena memberikan jaminan dan seleksi saat membeli produk. (Aaker, 1996; Buil et al., 2013; Keller and Lehmann, 2003; Rubio et al., 2014)

\section{Loyalty}

Menurut Keller, 2012 Brand Loyaltyadalah kuantifikasi keterkaitan yang di miliki konsumen terhadap merek tertentu. Sedangkan menurut para ahli telah menunjuk pada Brand Loyalty sebagai ekuitas merek, karena loyalitas merek meningkat dan kemungkinan konsumen beralih ke merek lain. (Keller, 2012; Villarejo-Ramos and Sanchez-Franco, 2005; Yo, et al., 2000; Aaker, 1991 dalam Beneke \& Zimmerman, 2014).Brand Loyaltydiartikan sebagai komitmen yang dipegang teguh untuk membeli kembali barang yang disukai secara konsisten di masa depan, mengurangi pengaruh situasional, menunjukkan pengaruh yang kuat pada niat pembelian. (Oliver,1997; De Wulf et al., 2005; Rondan et al., 2006). Menurut Aaker, 1991 loyalitas merek didefinisikan sebagai keterikatan yang dimiliki pelanggan dengan merek, yang mencerminkan seberapa besar kemungkinan pelanggan akan beralih ke merek lain. Loyalitas merek terkait dengan perilaku pembelian berulang dari waktu ke waktu dengan perilaku yang positif terhadap pilihan produk atau pilihan merek, berlabel, atau bervariasi. (Jagdish and Sheth, 1974 dalam Beneke \& Zimmerman, 2014)

\section{Store Image}

Store Image adalah kelengkapan komposisi (baik fakta maupun tidak) yang dicari konsumen pada ritel tertentu. (Baker et al., 1994, Keaveney and Hunt, 1992, Kunkel and Berry, 1968, dan ,Martineau, 1958). Sedangkan menurut Berstain dan Zorilla, 2011 dalam Beneke \& Zimmerman, 2014 mengidentifikasi Store Image sebagai hubungan kerjasama oleh merek komersial yang berkaitan dengan outlet di pikiran konsumen. Store Image berpengaruh pada keadaan yang dirasakan Private Label Brand (PLB). (Berstein and Zorilla, 2011, Vahie and Paswan, 2006, Collins-Dodd and Lindley, 2003, Semeijn et al., 2004). Menurut Huve-Nabec, 2002 Store Image did efinisikan sebagai rangkaian asosiasi merek yang terkait dengan toko diingatan konsumen. Sedangkan Aliawadi and Keller, 2014 mendefinisikan Store Image sebagai kesan pengecer dalam benak konsumen. Kesan ditentukan oleh kombinasi kompleks dari kedua atribut fungsional dan psikologis yang terkait dengan pengecer. (Beneke \& Zimmerman, 2014)

\section{Perceived Price}

Menurut Jacob and Olson, 1977 dalam Beneke \& Zimmerman, 2014Perceived Price meliputi konsumen, oleh karena itu harga yang di rasakan beragam di antara produk, situasi, dan waktu pembelian. Menurut penulis Xia et al, 2004 dan Slonim 
\&Garbarino, 1999 dalam Beneke \& Zimmerman, 2014Perceived Price akan mencerminkan nilai nya ketika konsumen sudah membeli. Berstein and Zorilla, 2011; Sweeney and Soutar, 2001; Yoo et al, 2000 mendefinisikanPerceived Price sebagaimana yang ditafsirkan oleh konsumen, karena ini mencerminkan nilai yang dianggap berasal dari produk oleh pembeli setelah membeli. (Beneke \& Zimmerman, 2014. Sedangkan menurut Zeithmal, 1988 dalam Beneke \& Zimmerman, 2014 yang menunjukkan bahwa konsumen tidak ingat harga produk yang tepat, sebaliknya mereka mengubah harga dengan cara yang berarti bagi mereka

\section{RERANGKA KONSEPTUAL}

\section{GAMBAR 1}

\section{MODEL PENELITIAN}

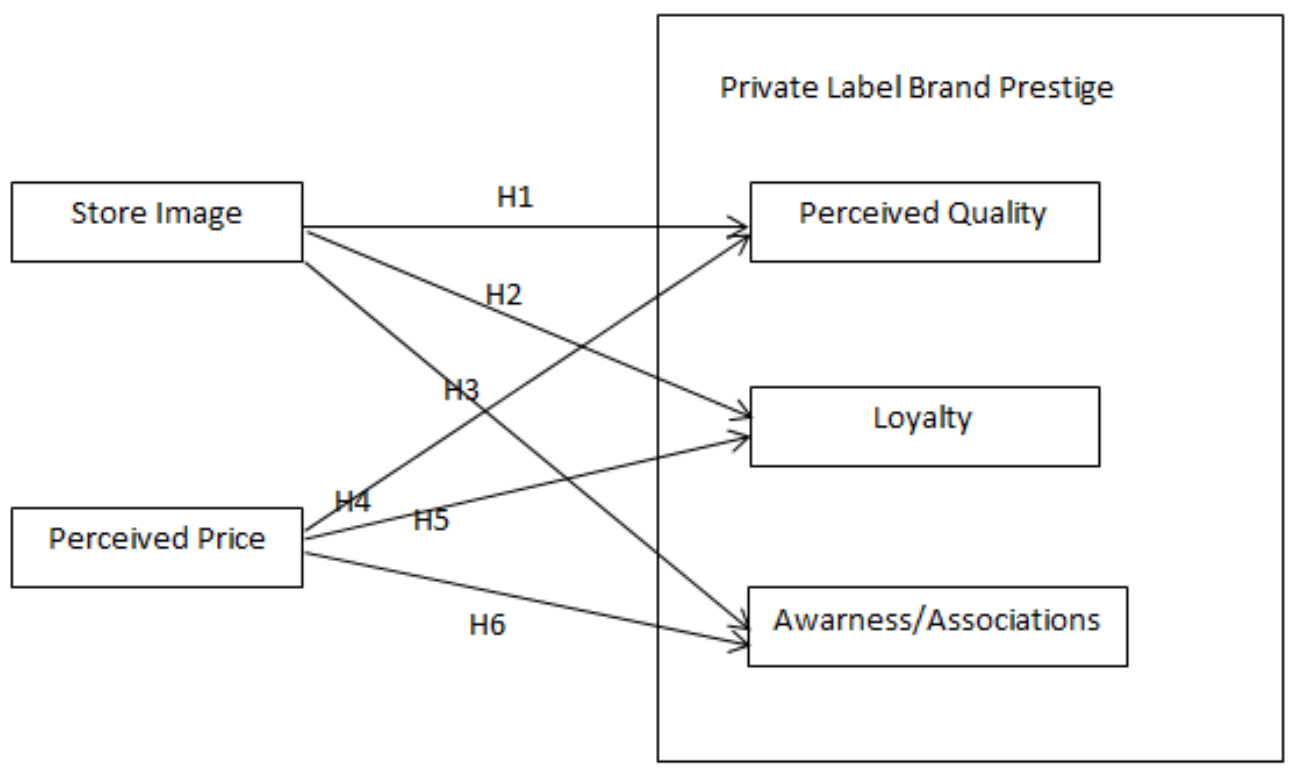

Sumber : Justin Beneke Natalia Zimmerman (2014)

\section{H1 : Pengaruh Store Image terhadap Perceived Quality}

Collins-Dodd and Lindley, 2003; Dick et al., 1996 mengusulkan bahwa ketika membuat keputusan kualitas, konsumen melihat dari kemasan dan yang terkandung didalamnya berfungsi sebagai petunjuk kualitas. Collins-Dodd and Lindley, 2003 mengusulkan bahwa store image cenderung menjadi petunjuk kualitas konsumen. Petunjuk dari kemasanadalah tanda terkait dengan produk yang tidak tertanam didalamnya, seperti store image, harga, kemasan dan nama merek. Petunjuk yang terkandung didalamnya adalah sifat fisik produk, seperti rasa produk, bahan, aroma dan tekstur. (Collins-Dodd and Lindley, 2003; Dick et al., 1996 dalam Beneke \& Zimmerman, 2014)Menurut Teas and Agarwal, 2000; Dick et al., 1996 bahwa penilaian petunjuk yang terkandung didalamnya menjadi pilihan yang sulit, konsumen lebih 


\section{National Conference of Creative Industry: \\ Sustainable Tourism Industry for Economic Development}

Universitas Bunda Mulia, Jakarta, 5-6 September 2018

E- ISSN No: 2622-7436

bergantung pada petunjuk dari kemasan untuk memastikan kualitas produk. Para ilmuwan berpendapat bahwastore image adalah salah satu tanda yang digunakan konsumen untuk menentukan kualitas private label brand. Dengan demikian, diharapkan bahwa hasil citra toko yang lebih menguntungkan dalam persepsi peningkatan kualitas private label brand. (Berstein and Zorilla, 2011; Lijander et al., 2009; Semeijen et al., 2004; Dick et al., 1996 and Richardson et al., 1996 dalam Beneke \& Zimmerman, 2014)

\section{H2 : Pengaruh Store Image terhadapLoyalty}

Berdasarkan hasil temuan dari (Bloemer and de Ruyter, 1998 dalam Beneke \& Zimmerman, 2014) menunjukkan bahwa perlindungan konsumen dari toko tertentu tergantung pada citra yang melekat padanya.Yoo et al, 2000dalam Beneke \& Zimmerman, 2014melaporkan bahwa sementara tidak ada hubungan antara citra toko dan loyalitas produk merek nasional, rancangan saat ini mungkin sangat berbeda sehubungan dengan private label brand.Menurut Osman, 1993 dalam Beneke \& Zimmerman, 2014 perilaku pelanggan terhadap toko tertentu bergantung pada citra mereka tentang toko tertentu. Semakin bagus citra toko, semakin tinggi derajat toko bagi pelanggan. Namun, hubungan yang tepat antara citra toko dan loyalitas toko tetap tidak meyakinkan. Ada bukti untuk hubungan langsung dan tidak langsunghubungan dimana kepuasan toko bertindak sebagai mediator (Doyle dan Fenwick, 1974; Houston dan Nevin, 1981; Lindquist, 1974; Stanley dan Sewall, 1976 dalam Beneke \& Zimmerman, 2014). Collins-Dodd dan Lindley, 2003 dalam Beneke \& Zimmerman, 2014 menyarankan bahwa private label brand yang konsisten dengan citra toko mungkin mendapatkan loyalitas merek karena asosiasi ini. Ini dikonfirmasi oleh Beristain dan Zorrilla (2011) dalam penelitian mereka. Dengan demikian, penulis berpendapat bahwa memang ada hubungan kausal antara citra toko dan loyalitas private label brand.

\section{H3 : Pengaruh Store Image terhadap Brand Awareness}

Collins-Dodd and Lindley, 2003 menegaskan bahwa ada hubungan fungsional antara store image dan citra merek label pribadi.Karena private label brand adalah kekayaan kelompok ritel, kemasan yang diberikan oleh pengecer cenderung sangat mempengaruhi private label brand mereka, dengan beberapa konsumen bahkan melihat merek-merek ini sebagai perluasan merek ritel itu sendiri. (Berstein and Zorilla, 2011; Collins-Dodd and Lindley, 2003 dalam Beneke \& Zimmerman, 2014). Oleh karena itu kemasan yang disediakan oleh toko harus jauh lebih baik daripada merek nasional. Vahie and paswan, 2006 dalam Beneke \& Zimmerman, 2014menemukan hubungan positif antarastore image dan brand image. Studi empiris mereka menunjukkan bahwa store imagetidak hanya mempengaruhi dimensi kualitas store image tetapi juga makna dimensinya.

\section{H4 : Pengaruh Perceived Price terhadap Perceived Quality}

Berdasarkan penelitian dari (Jin dan Suh, 2005; Dick et al., 1996; Dodds et al., 1991; Zeithaml, 1988; Monroe dan Krishnan, 1985 dalam Beneke \& Zimmerman, 2014)harga berfungsi sebagai pilihan kualitas produk Jika suatu produk diatur pada titik 


\section{National Conference of Creative Industry: \\ Sustainable Tourism Industry for Economic Development}

Universitas Bunda Mulia, Jakarta, 5-6 September 2018

E- ISSN No: 2622-7436

harga rendah, ini menandakan bahwa produk tersebut mungkin berkualitas rendah dan sebaliknya (Collins-Dodd dan Lindley, 2003; Dick et al., 1996). Peterson dan Wilson (1985, p. 246) menyimpulkan bahwa hubungan kualitas yang dirasakan dengan harga yang dirasakan tidak terlalu kuat. Meskipun sejumlah peneliti yang secara langsung atau tidak langsung menguji hubungan kualitas yang dirasakan dan harga yang dirasakan, tidak jelas apakah kita telah menentukan batas kapan, dan dalam kondisi apa, pembeli menghubungkan kualitas berdasarkan harga dan informasi lainnya (Monroe dan Dodds 1988 ; Peterson dan Wilson 1985 dalam Beneke \& Zimmerman, 2014). Menurut Jacoby dan Olson, 1977 dalam Beneke \& Zimmerman, 2014 harga memiliki sifatobyektif eksternal dan mewakilkan subjektif internal yang berasal dari persepsi harga, sehingga menghasilkan beberapa makna bagi konsumen. Harga dapat menjadi indikator yang diperlukan untuk membeli produk. Harga yang lebih tinggi menyebabkan kualitas lebih tinggi maka dari itu meningkatkan keinginan yang lebih besar untuk membeli. (Scitovszky, 1945 dalam Beneke \& Zimmerman, 2014)

\section{H5 : Pengaruh Perceived Price terhadap Brand Awareness}

Menurut Keller, 2012 dan Aaker, 1991 suatu asosiasi dapat menciptakan dasar penting untuk perbedaan. Hal ini terutama berlaku dalam kasusprivate label brand, di mana orientasi nilai telah digunakan untuk mendorong volume penjualan ritel yang baik. (Beristain dan Zorrilla, 2011;Beneke, 2010; Kumar dan Steenkamp, 2007 dalam Beneke \& Zimmerman, 2014). Beristain dan Zorrilla, 2011 menyarankan bahwa private label branddapat membuat manfaat psikologis terkait dengan penghematan yang terkait dengan akuisisi label pribadi, serta karakter konsumen.Pearson, 2012 berpendapat bahwa produk berkualitas dengan harga terjangkau dapat menciptakan proposisi menarik untuk konsumen yang sadar akan nilai, sehingga membentuk kesadaran mereka, dan asosiasi dengan merek. Jika harga, yang dirasakan berbeda dari karakteristik "obyektifnya", pembeli cenderung menggunakan proses perseptual yang sama untuk nama merek dan toko.(Zeithaml, 1988 dalam Beneke \& Zimmerman, 2014)

\section{H6 : Pengaruh Perceived Price terhadap Loyalty}

Perbedaan harga ini sering menjadi faktor dalam proses pembelian dan, sebagai hasilnya, Beristain dan Zorrilla, 2011; Richardson et al., 1996 dalam Beneke \& Zimmerman, 2014). Sedangkan Yoo et al, 2000 berbicara tentang merek produsen, bahwa tidak ada hubungan yang jelas antara variabel-variabel yang disebutkan; jika citra pengecer tidak sesuai dengan citra produk yang dirasakan, tidak akan cukup bagi konsumen untuk menunjukkan kesetiaan, dan dengan demikian kesetiaan tidak perlu terpengaruh baik secara positif maupun negatif.Generasi pembeli berulang yang berkomitmen telah menjadi tujuan utama pemasar untuk pemasaran yang kurang menuntut sumber daya merekrut karyawan baru dan loyalitas telah digunakan sebagai ukuran keberhasilan strategi pemasaran dan ukuran parsial ekuitas merek (Knox \& Walker, 2001, p.121; Knox \& Walker, 2001; Reichheld \&Sasser, 1990; Reichheld, 1996; Birgelen, 1997 dalam Beneke \& Zimmerman, 2014). Sedangkan Keller, 1993; $\mathrm{Na}$, Marshall \& Keller, 1999 menganggapnya sebagai konsekuensi dari asosiasi merek yang kuat. Konsep loyalitas toko telah berevolusi dari kesetiaan merek sehubungan dengan barang berwujud (Cunningham, 1956 dalam Beneke \& Zimmerman, 2014). 


\section{METODE PENELITIAN}

Populasi yang diambil dalam penelitian ini adalah konsumen yang pernah berbelanja produk private label di Supermarket Hero. Dengan teknik pengambilan sampel menggunakan non probablity sampling. Melalui metode pengumpulan data kuesioner maka sampel yang berhasil dikumpulkan dalam penelitian ini berjumlah 180 responden. Kuesioner yang dikumpulkan akan melalui skala likert dan dianalisa dengan bantuan SMARTPLS 03.Selanjutnya data akan diuji kembali melalui rule of thumb yang menjadi pengukuran

\section{OPERASIONALISASI VARIABEL}

TABEL 1

Operasionalisasi Variabel

\begin{tabular}{|c|c|c|}
\hline Variabel & Indikator & Sumber \\
\hline Store Image & $\begin{array}{l}\text { 1. Saya suka berbelanja di Supermarket } \\
\text { Hero karena tempat nya menyenangkan } \\
\text { 2. Saya suka berbelanja di Supermarket } \\
\text { Hero karena tempat nya sangat nyaman } \\
\text { 3. Saya suka berbelanja di Supermarket } \\
\text { Hero karena tempatnya bersih } \\
\text { 4. Saya suka berbelanja di Supermarket } \\
\text { Hero karena tempat nya menarik }\end{array}$ & $\begin{array}{l}\text { Baker, Julie., } \\
1994\end{array}$ \\
\hline $\begin{array}{l}\text { Perceived } \\
\text { Price }\end{array}$ & $\begin{array}{l}\text { 1. Saya merasa harga tissue hero terjangkau } \\
\text { 2. Saya merasa harga tissue hero tidak mahal } \\
\text { 3. Saya merasa harga tissue hero sesuai } \\
\text { dengan kualitasnya } \\
\text { 4. Saya merasa tissue hero lebih terjangkau } \\
\text { dari pada tissue merek lain }\end{array}$ & $\begin{array}{l}\text { Jose Juan } \\
\text { Beristain, } \\
2011\end{array}$ \\
\hline $\begin{array}{l}\text { Perceived } \\
\text { Quality }\end{array}$ & $\begin{array}{l}\text { 1. Saya menganggap tissue hero } \\
\text { memiliki kualitas yang tinggi } \\
\text { 2. Saya merasa tissue hero membuat } \\
\text { saya percaya akan kualitasnya yang } \\
\text { bagus } \\
\text { 3. Saya merasa tissue hero adalah produk } \\
\text { yang saya cari, karena kualitasnya } \\
\text { yang bagus }\end{array}$ & $\begin{array}{l}\text { Jose Juan } \\
\text { Beristain, } \\
2011\end{array}$ \\
\hline Loyalty & $\begin{array}{l}\text { 1. Saya menganggap diri saya sebagai } \\
\text { konsumen setia tissue hero } \\
\text { 2. Saya membeli tissue hero sebagai opsi } \\
\text { pertama } \\
\text { 3. Saya akan terus membeli tissue hero }\end{array}$ & $\begin{array}{l}\text { Jose Juan } \\
\text { Beristain, } \\
2011\end{array}$ \\
\hline
\end{tabular}


National Conference of Creative Industry:

Sustainable Tourism Industry for Economic Development

Universitas Bunda Mulia, Jakarta, 5-6 September 2018

E- ISSN No: 2622-7436

\begin{tabular}{|l|l|l|}
\hline Brand & 1. Saya akan memberikan informasi & Jose Juan \\
pada teman-teman untuk membeli & Beristain, \\
tissue di Supermarket Hero & 2011 \\
2. Saya selalu berfikir positif tentang & & \\
produk dan harga di Supermarket & Hero & \\
3. $\begin{array}{l}\text { Saya merasa Supermarket Hero aalah } \\
\text { tempat yang tepat untuk berbelanja } \\
\text { kebutuhan sehari-hari }\end{array}$ & \\
\hline
\end{tabular}

\section{HASIL PENELITIAN DAN PEMBAHASAN}

Berdasarkan hasil pengumpulan data, maka diasikan profil responden yang terdapat dalam penelitian ini, antara lain:

TABEL 2

PROFIL RESPONDEN KONSUMEN SUPERMARKET HERO

\begin{tabular}{|c|c|c|c|}
\hline $\begin{array}{l}\text { Variabel } \\
\text { Demografis }\end{array}$ & Kategori & Frekuensi & Persentase \\
\hline \multirow{2}{*}{ Jenis Kelamin } & Wanita & 105 & $58 \%$ \\
\hline & Pria & 75 & $42 \%$ \\
\hline \multirow{6}{*}{ Usia Responden } & $<17$ Tahun & 11 & $6 \%$ \\
\hline & 17-24 Tahun & 112 & $62 \%$ \\
\hline & 24-31 Tahun & 39 & $22 \%$ \\
\hline & 31-38 Tahun & 5 & $3 \%$ \\
\hline & 38-45 Tahun & 10 & $5 \%$ \\
\hline & $>45$ Tahun & 3 & $2 \%$ \\
\hline \multirow{5}{*}{$\begin{array}{l}\text { Pekerjaan } \\
\text { Responden }\end{array}$} & Pelajar/Mahasiswa & 84 & $47 \%$ \\
\hline & Karyawan & 62 & $34 \%$ \\
\hline & Wiraswasta & 19 & $10 \%$ \\
\hline & Ibu Rumah Tangga & 14 & $8 \%$ \\
\hline & Lainnya & 1 & $1 \%$ \\
\hline \multirow{4}{*}{$\begin{array}{l}\text { Pengeluaran dalam } \\
\text { satu bulan saat } \\
\text { berbelanja di Hero }\end{array}$} & $<100.000$ & 27 & $15 \%$ \\
\hline & $100.000-400.000$ & 126 & $70 \%$ \\
\hline & $400.000-1.000 .000$ & 21 & $12 \%$ \\
\hline & $>1.000 .000$ & 6 & $3 \%$ \\
\hline \multirow{5}{*}{$\begin{array}{l}\text { Domisili } \\
\text { Responden }\end{array}$} & Jakarta Utara & 29 & $16 \%$ \\
\hline & Jakarta Barat & 39 & $22 \%$ \\
\hline & Jakarta Selatan & 41 & $23 \%$ \\
\hline & Jakarta Timur & 35 & $19 \%$ \\
\hline & Jakarta Pusat & 36 & $20 \%$ \\
\hline
\end{tabular}

Sumber : data primer $(n=180)$ 
Tabel 4.1 menggambarkan profil responden Supermarket Hero dengan total 180 responden. Mayoritas responden berjenis kelamin wanita dengan jumlah 105 responden (58\%), berumur antara 17-24 tahun dengan total 112 responden (62\%), memiliki pekerjaan sebagai pelajar/mahasiswa dengan jumlah 84 (47\%), pengeluaran konsumen saat berbelanja di Supermarket Hero 100,000 sampai 400,000 rupiah dengan jumlah 126 (70\%), dan berdomisili di Jakarta Selatan dengan jumlah 41 (23\%).

Berdasarkan data diatas, dapat dijelaskan bahwa konsumen yang sering berbelanja di Supermarket Hero dan pernah membeli tissue Hero berusia 17-24 tahun dan pekerjaan responden sebagai pelajar/mahasiswa dengan pengeluaran saat berbelanja di Supermarket Hero 100,000-400,000. Data tersebut menjelaskan karena mereka berbelanja kebutuhan sehari-hari, yang berhubungan dengan sekolah, kuliah ataupun kepentingan pribadi mereka yang menyebabkan mereka berkunjung dan berbelanja di Supermarket Hero dan rata-rata konsumen yang berbelanja di Supermarket Hero berada di Jakarta Selatan, dikarenakan Supermarket Hero lebih banyak tersebar di daerah Jakarta Selatan.

\section{ANALSISIS DATA}

\section{Uji Validitas}

Hasil uji validitas berikut adalah hasil perhitungan dari keseluruhan data konsumen Supermarket Hero.

1. Uji validitas konvergen

TABEL 3

AVE SUPERMARKET HERO

\begin{tabular}{|l|c|}
\hline & $\begin{array}{l}\text { Average Variance Extracted } \\
\text { (AVE) }\end{array}$ \\
\hline Brand Awareness & 0.776 \\
\hline Loyalty & 0.818 \\
\hline Perceived Price & 0.761 \\
\hline Perceived Quality & 0.839 \\
\hline Store Image & 0.779 \\
\hline
\end{tabular}

Sumber: Data Primer $(n=180)$

Hasil AVE Supermarket Hero pada tabel 4.3 menunjukkan seluruh variabel telah memenuhi syarat convergent dan reliabilitas yaitu nilai AVE $>0,5$ sehingga data dapat dinyatakan valid. 
National Conference of Creative Industry:

Sustainable Tourism Industry for Economic Development

Universitas Bunda Mulia, Jakarta, 5-6 September 2018

E- ISSN No: 2622-7436

TABEL 4

OUTER LOADING SUPERMARKET HERO

\begin{tabular}{|c|c|c|c|c|c|}
\hline & $\begin{array}{c}\text { Brand } \\
\text { Awareness }\end{array}$ & Loyalty & $\begin{array}{c}\text { Perceived } \\
\text { Price } \\
\end{array}$ & $\begin{array}{c}\text { Perceived } \\
\text { Quality }\end{array}$ & $\begin{array}{l}\text { Store } \\
\text { Image } \\
\end{array}$ \\
\hline BA 1 & 0.855 & & & & \\
\hline BA 2 & 0.903 & & & & \\
\hline BA 3 & 0.894 & & & & \\
\hline BA 4 & 0.871 & & & & \\
\hline L 1 & & 0.902 & & & \\
\hline L 2 & & 0.913 & & & \\
\hline L 3 & & 0.899 & & & \\
\hline PP 1 & & & 0.862 & & \\
\hline PP 2 & & & 0.872 & & \\
\hline PP 3 & & & 0.890 & & \\
\hline PP 4 & & & 0.865 & & \\
\hline PQ 1 & & & & 0.907 & \\
\hline PQ 2 & & & & 0.938 & \\
\hline PQ 3 & & & & 0.902 & \\
\hline SI 1 & & & & & 0.890 \\
\hline SI 2 & & & & & 0.881 \\
\hline SI 3 & & & & & 0.867 \\
\hline SI 4 & & & & & 0.893 \\
\hline
\end{tabular}

Sumber : Data Primer $(\mathbf{n}=\mathbf{1 8 0})$

Pada tabel outer loading Supermarket Hero (tabel 4.2) dapat dilihat bahwa data memenuhi construct validity karena variabel manifest (indikator)nya berkelompok sesuai dengan variabel latennya. Nilai outer loading variabel manifest (indikator) semuanya memenuhi rule of thumb convergent validity yaitu senilai > 0,6.

2. Uji validitas diskriminan

Berdasarkan tabel 4.4 yang akan di sajikan, dapat dilihat secara seksama bahwa nilai pada kolom kuning (hasil pengukuran indikator terhadap variabel laten yang diukur) memiliki nilai yang lebih tinggi dibandingkan nilai pada kolom merah (hasil pengukuran indikator terhadap variabel laten lainnya) sehingga bisa disimpulkan bahwa discriminant validity terpenuhi, dan data dapat dinyatakan valid. 
National Conference of Creative Industry:

Sustainable Tourism Industry for Economic Development

Universitas Bunda Mulia, Jakarta, 5-6 September 2018

E- ISSN No: 2622-7436

TABEL 5

CROSS LOADING SUPERMARKET HERO

\begin{tabular}{|c|c|c|c|c|c|}
\hline & $\begin{array}{c}\text { Brand } \\
\text { Awareness }\end{array}$ & Loyalty & $\begin{array}{l}\text { Perceived } \\
\text { Price }\end{array}$ & $\begin{array}{l}\text { Perceived } \\
\text { Quality }\end{array}$ & $\begin{array}{c}\text { Store } \\
\text { Image }\end{array}$ \\
\hline $\begin{array}{l}\mathbf{B A} \\
2\end{array}$ & 0.903 & 0.604 & 0.675 & 0.628 & 0.603 \\
\hline $\begin{array}{l}\mathbf{B A} \\
\mathbf{3}\end{array}$ & 0.894 & 0.603 & 0.682 & 0.599 & 0.662 \\
\hline $\begin{array}{l}\text { BA } \\
4\end{array}$ & 0.871 & 0.513 & 0.622 & 0.558 & 0.608 \\
\hline L 1 & 0.647 & 0.902 & 0.626 & 0.729 & 0.59 \\
\hline L 2 & 0.603 & 0.913 & 0.662 & 0.73 & 0.627 \\
\hline L 3 & 0.64 & 0.899 & 0.669 & 0.706 & 0.569 \\
\hline PP 1 & 0.677 & 0.574 & 0.862 & 0.621 & 0.544 \\
\hline PP 2 & 0.66 & 0.62 & 0.872 & 0.643 & 0.625 \\
\hline PP 3 & 0.705 & 0.634 & 0.89 & 0.721 & 0.664 \\
\hline PP 4 & 0.607 & 0.685 & 0.865 & 0.703 & 0.643 \\
\hline $\begin{array}{l}\text { PQ } \\
1\end{array}$ & 0.673 & 0.763 & 0.727 & 0.907 & 0.694 \\
\hline $\begin{array}{l}\mathbf{P Q} \\
2\end{array}$ & 0.667 & 0.733 & 0.714 & 0.938 & 0.658 \\
\hline $\begin{array}{l}\text { PQ } \\
3\end{array}$ & 0.593 & 0.693 & 0.677 & 0.902 & 0.57 \\
\hline SI 1 & 0.636 & 0.634 & 0.667 & 0.654 & 0.89 \\
\hline SI 2 & 0.638 & 0.594 & 0.63 & 0.593 & 0.881 \\
\hline SI 3 & 0.651 & 0.525 & 0.605 & 0.595 & 0.867 \\
\hline SI 4 & 0.591 & 0.566 & 0.606 & 0.633 & 0.893 \\
\hline
\end{tabular}

Berdasarkan hasil pengujian construct, convergent, dan discriminant validity tersebut maka dapat dinyatakan bahwa variabel manifest (indikator) memenuhi ketiga syarat uji validitas tersebut sehingga indikator yang digunakan untuk mengukur variabel laten dinyatakan valid.

\section{Uji Reliabilitas}

Hasil uji reliabilitas berikut adalah hasil perhitungan dari keseluruhan data konsumen Supermarket Hero. 
National Conference of Creative Industry:

Sustainable Tourism Industry for Economic Development

Universitas Bunda Mulia, Jakarta, 5-6 September 2018

E- ISSN No: 2622-7436

TABEL 6

HASIL UJI RELIABILITAS SUPERMARKET HERO

\begin{tabular}{|l|c|c|}
\hline & Cronchbach Alfa & Composite Realibilty \\
\hline Brand Awareness & 0.904 & 0.933 \\
\hline Loyalty & 0.889 & 0.931 \\
\hline Perceived Price & 0.895 & 0.927 \\
\hline Perceived Quality & 0.904 & 0.940 \\
\hline Store Image & & \\
\hline
\end{tabular}

Sumber : data primer $(n=180)$

Hasil uji reliabilitas Supermarket Hero menunjukkan cronbach's alpha memiliki nilai berkisar dari 0.889 - 0.905 dan composite reliability memiliki nilai yang berkisar antara 0.904 - 0.940 yang dapat dilihat lengkap pada tabel hasil uji reliabilitas Supermarket Hero (tabel 4.5) data ini menunjukkan bahwa instrumen yang digunakan untuk menghitung konstruk dapat dinyatakan akurat, konsisten, dan tepat.

\section{Uji Korelasi}

Nilai pada tabel latent variabel correlation (tabel 4.6) dibawah ini menunjukkan jika nilai korelasi, antara lain:

TABEL 7

LATENT VARIABEL CORRELATION SUPERMARKET HERO

\begin{tabular}{|c|c|c|c|c|c|}
\hline & $\begin{array}{c}\text { Brand } \\
\text { Awareness }\end{array}$ & Loyalty & $\begin{array}{c}\text { Perceived } \\
\text { Price }\end{array}$ & $\begin{array}{c}\text { Perceived } \\
\text { Quality }\end{array}$ & $\begin{array}{c}\text { Store } \\
\text { Image }\end{array}$ \\
\hline Loyalty & 0.696 & 1 & & & \\
\hline $\begin{array}{c}\text { Perceived } \\
\text { Price }\end{array}$ & 0.759 & 0.721 & 1 & & \\
\hline $\begin{array}{c}\text { Perceived } \\
\text { Quality }\end{array}$ & 0.705 & 0.798 & 0.772 & 1 & \\
\hline Store Image & 0.713 & 0.658 & 0.711 & 0.702 & 1 \\
\hline
\end{tabular}

Sumber: data primer $(n=180)$

Berdasarkan hasil pada tabel 4.6 diatas menunjukkan bahwa setiap variabel memiliki pengaruh yang positif.

\section{Hasil Uji Koefisien Determinasi}

Berikut ini adalah hasil uji koefisien determinasi yang menggambarkan pengaruh dari satu atau lebih dari dua variabel laten eksogen terhadap variabel laten endogennya. 
TABEL 8

HASIL R-SQUARE SUPERMARKET HERO

\begin{tabular}{|c|c|}
\hline & R Square \\
\hline Brand Awareness & 0.637 \\
\hline Loyalty & 0.563 \\
\hline Perceived Quality & 0.643 \\
\hline
\end{tabular}

Sumber : Data Primer $(\mathbf{n}=180)$

Berdasarkan nilai pada tabel 4.7 maka dapat diartikan bahwa: Brand awareness dipengaruhi oleh store image dan perceived price sebesar $63,7 \%$ selebihnya dipengaruhi oleh faktor lain yang tidak diteliti dalam penelitian ini.. Loyalty dipengaruhi oleh store image dan perceived price sebesar 56,3\% selebihnya dipengaruhi oleh faktor lain yang tidak diteliti dalam penelitian ini.Perceived quality dipengaruhi oleh store image dan perceived price sebesar $64,3 \%$ selebihnya dipengaruhi oleh faktor lain yang tidak diteliti dalam penelitian ini

TABEL 9

\section{Hasil Hipotesa}

\begin{tabular}{|c|c|c|}
\hline \multicolumn{2}{|c|}{ Hipotesa } & Supermarket Hero \\
\hline $\mathrm{H} 1$ & $\begin{array}{l}\text { H0 : Tidak terdapat pengaruh antara store } \\
\text { image terhadap perceived quality. } \\
\text { H1 : Terdapat pengaruh antara store image } \\
\text { terhadap perceived quality. }\end{array}$ & $\begin{array}{l}3,689>1,96 \\
\text { H1 diterima }\end{array}$ \\
\hline $\mathrm{H} 2$ & $\begin{array}{l}\text { H0 : Tidak terdapat pengaruh antara store } \\
\text { image terhadap loyalty. } \\
\text { H1 : Terdapat pengaruh antara store image } \\
\text { terhadap loyalty. }\end{array}$ & $\begin{array}{c}3,263>1,96 \\
\text { H2diterima }\end{array}$ \\
\hline H3 & $\begin{array}{l}\text { H0 : Tidak terdapat pengaruh antara store } \\
\text { image terhadap brand awareness. } \\
\text { H1 : Terdapat pengaruh antara store image } \\
\text { terhadap brand awareness. }\end{array}$ & $\begin{array}{l}3,052>1,96 \\
\text { H3 diterima }\end{array}$ \\
\hline $\mathrm{H} 4$ & $\begin{array}{l}\text { H0 : Tidak terdapat pengaruh antara } \\
\text { perceived price terhadap perceived quality. } \\
\text { H1 : Terdapat pengaruh antara perceived } \\
\text { price terhadap perceived quality. }\end{array}$ & $\begin{array}{l}7,039>1,96 \\
\text { H4 diterima }\end{array}$ \\
\hline
\end{tabular}




\begin{tabular}{|c|c|c|}
\hline H5 & $\begin{array}{l}\text { H0 : Tidak terdapat pengaruh perceived } \\
\text { price terhadap loyalty. } \\
\text { H1 : Terdapat pengaruh antara perceived } \\
\text { price terhadap loyalty. }\end{array}$ & $\begin{array}{l}6,356>1,96 \\
\text { H5 diterima }\end{array}$ \\
\hline H6 & $\begin{array}{l}\text { H0 : Tidak terdapat pengaruh perceived } \\
\text { price terhadap brand awareness. } \\
\text { H1 : Terdapat pengaruh antara perceived } \\
\text { price terhadap brand awareness. }\end{array}$ & $\begin{array}{l}5,383>1,96 \\
\text { H6 diterima }\end{array}$ \\
\hline
\end{tabular}

\section{Hasil Uji Signifikansi}

Hasil nilai dari uji signifikansi Supermarket Hero dapat dilihat pada tabel path coefficient Supermarket Hero (tabel 4.8) dibawah ini.

TABEL 10

PATH COEFFICIENT SUPERMARKET HERO

\begin{tabular}{|c|c|}
\hline & T Statistics $(|\mathbf{O} / \mathbf{S T D E V}|)$ \\
\hline Perceived Price -> Brand Awareness & 5.383 \\
\hline Perceived Price -> Loyalty & 6.356 \\
\hline Perceived Price -> Perceived Quality & 7.039 \\
\hline Store Image -> Brand Awareness & 3.052 \\
\hline Store Image -> Loyalty & 3.263 \\
\hline Store Image -> Perceived Quality & 3.689 \\
\hline
\end{tabular}

Sumber : Data Primer $(n=180)$

Dari hasil path coefficient diatas maka dapat dilihat adanya pengaruh yang signifikan antara perceived price terhadap brand awareness, loyalty dan perceived quality antara store image terhadap brand awareness, loyalty, dan perceived quality.

\section{KESIMPULAN DAN IMPLIKASI}

Berdasarkan hasil penilitan ini maka terdapat berbagai temuan antara lain: Store Image memiliki pengaruh yang signifikan terhadap Perceived quality pada Supermarket Hero, hal ini sesuai dengan hasil penelitian dari Justin Beneke, Natalia Zimmerman yang dalam temuanya memiliki pengaruh yang positif dan signifikan. Melihat hal ini sebagai pemilik gerai hero untuk menjadikan produk private label menjadiu produk unggulan dapat memperkuat kembali citra toko agar kualitas yang dirasakan konsumen semakin tinggi, memberikan dampak kepada loyalitas dan brand awareness kepada konsumen, Cara lainnya dapat mengatur kembali strategi harga agar harga yang 


\section{National Conference of Creative Industry: \\ Sustainable Tourism Industry for Economic Development}

Universitas Bunda Mulia, Jakarta, 5-6 September 2018

E- ISSN No: 2622-7436

dirasakan konsumen dapat sesuai (tidak terlalu mahal ataupun terlalu murah) agar citra dari private label tetap terjaga. Melalui penelitian ini terdapat berbagai saran yang dapat dilakukan untuk penelitian selanjutnya seperti mengelompokan private label kedalam kebutuhan primer (sandang, pangan, papan) untuk mengkaji kembali nilai ekuitas merek dimata konsumen.Peneliti selanjutnya dapat mengkaji kembali kemasan produk private label melalui kajian intrinsic maupun ekstrinsic untuk mengukur ekuitas merek

\section{DAFTAR PUSTAKA}

Abdillah, Willy dan Jogiyanto Hartono (2015), Partial least square: Alternatif Structural Equation Modeling (SEM) dalam Penelitian Bisnis, Andi, Yogyakarta.

Arikunto, S. (2002), Prosedur Penelitian: Suatu Pendekatan Praktek, Renika Cipta, Jakarta.

Abril, C., \& Rodriguez-Cánovas, B. (2016). Marketing mix effects on private labels brand equity. European Journal of Management and Business Economics, 25(3), 168175 .

Baker, J., Grewal, D., \& Parasuraman, A. (1994). The influence of store environment on quality inferences and store image. Journal of the Academy of Marketing Science: Official Publication of the Academy of Marketing Science, 22(4), 328-339.

Beristain, J. J., \& Zorrilla, P. (2011). The relationship between store image and store brand equity: A conceptual framework and evidence from hypermarkets. Journal of Retailing and Consumer Services, 18(6), 562-574.

Beneke, J., \& Zimmerman, N. (2014). Beyond private label panache: the effect of store image and perceived price on brand prestige. Journal of Consumer Marketing, 31(4), 301-311.

Beneke, J. (2015). Article information: International Journal of Reta, 43(1), 43-62. http://doi.org/http://dx.doi.org/10.1108/MRR-09-2015-0216

Bloemer, J., \& de Ruyter, K. (1998). On the relationship between store image, store satisfaction and store loyalty. European Journal of Marketing, 32(5/6), 499-513.

Cengiz, E., \& Kirkbir, F. (2007). Customer perceived value: The development of a multiple item scale in hospitals. Problems and Perspectives in Management, 5(3), $252-268$.

Hair, et.al. (2010). Multivariate Data Analysis. United States: Perason Pretince Hall.

Levy, Michael; Weitz, Baron A; Grewal, Dhruv. (2014) Retailing Management 9th edition. New York : McGrawHill.

Latan, H., \& Ghozali, I. (2015). Partial Least Square Konsep, Teknik dan Aplikasi Smart PLS 3.0. Semarang : Badan Penerbit Universitas Diponegoro.

Malhotra, N. K. (2012). Basic Marketing Research: Integration of Social Media, 


\section{National Conference of Creative Industry: \\ Sustainable Tourism Industry for Economic Development}

Universitas Bunda Mulia, Jakarta, 5-6 September 2018

E- ISSN No: 2622-7436

Pearson Education.

Sasmita, J., \& Mohd Suki, N. (2015). Young consumers' insights on brand equity. International Journal of Retail \& Distribution Management, 43(3), 276-292.

Sekaran, Uma; Bougie, Roger. 2010. Research Methods for Business: A Skill Building Approach (5thed.) United Kingdom : John Wiley \&Sons Ltd.

Sekaran, U., and Bougie, R. (2013). Research methods for bisiness. In U. Sekaran, and R. Bougie, Research methods for bisiness. Italy: John Wiley \& Sons Ltd.

Sugiyono. 2003. Metode Penelitian Bisnis. Bandung. Pusat Bahasa Depdiknas.

Sugiyono (2013). Statistika untuk Penelitian. Bandung: Alfabeta.

Tas, M., Balci, M., Yüksel, A., \& Yesilçubuk, N. S. (2015). British Food Journal. British Food Journal British Food Journal British Food Journal, 117(4), 14261439.

Utami, Chirstina W. 2010. "Manajemen Ritel: Strategi dan Implementasi Operasional Bisnis Ritel Modern di Indonesia." Jakarta: Salemba Empat.

Vahie, A., \& Paswan, A. (2006). Private label brand image: its relationship with store image and national brand. International Journal of Retail \& Distribution Management, 34(1), 67-84.

www.mix.co.iddi akses pada tanggal 21 Januari 2018 